\title{
Konferencje gerontologiczne z cyklu „Refleksje nad starością"
}

\begin{abstract}
Abstrakt
W artykule opisane zostały Konferencje gerontologiczne z cyklu „Refleksje nad starością”, które organizowane są przez Katedrę Andragogiki i Gerontologii Społecznej. Głównym celem tych konferencji było rozpoczęcie spotkań poświęconych tematyce szeroko rozumianego procesowi starości i starzenia się. W artykule przedstawiona została także nowa seria wydawnicza - „Refleksje nad starością”.
\end{abstract}

Słowa kluczowe: Katedra Andragogiki i Gerontologii Społecznej UŁ, konferencje gerontologiczne, publikacje naukowe.

\section{"Reflections on Old Age" Gerontology Conferences}

\begin{abstract}
The paper describes the "Reflections on Old Age" gerontology conferences organized by the Department of Andragogy and Social Gerontology. The main purpose of these conferences was to start fruitful meetings devoted to issues of old age and the process of ageing. The paper also presents a new editorial series entitled "Reflections on Old Age".
\end{abstract}

Keywords: Department of Andragogy and Social Gerontology at the University of Lodz, gerontology conferences, scientific publications.

\footnotetext{
* Uniwersytet Łódzki, Wydział Nauk o Wychowaniu, Katedra Andragogiki i Gerontologii Społecznej.
} 
Środowisko łódzkich gerontologów w sposób systematyczny, od wielu lat, podejmuje działania mające na celu rozwój gerontologii społecznej, a także geragogiki w wymiarze badawczym oraz praktycznych rozwiązań. Służą temu konferencje gerontologiczne oraz seria wydawnicza.

Konferencje zorganizowane przez Katedrę Andragogiki i Gerontologii Społecznej Uniwersytetu Łódzkiego odbywają się pod przewodnictwem prof. zw. dr hab. Elżbiety Dubas, a wśród sekretarzy konferencji należy wymienić: dra Marcina Muszyńskiego, dr Annę Gutowską oraz dr Monikę Chmielecką.

Pierwsza konferencja z cyklu „Refleksje nad starością” odbyła się w 2014 r., kolejne zaś następowały po sobie w dwuletnich przerwach. Spotkania obejmowały wystąpienia o charakterze referatowym oraz komunikaty z badań. Z roku na rok rosła liczebność zgłoszeń zarówno aktywnych, jak i biernych uczestników konferencji. Zgłoszenia napływały z całej Polski, a wśród uczestników odnaleźć można było zarówno naukowców o uznanym dorobku gerontologicznym, młodych badaczy stojących u progu swoich karier naukowych, jak i studentów stawiających pierwsze kroki badawcze. Wokół wydarzenia organizowanego przez Katedrę Andragogiki i Gerontologii Społecznej skupieni byli nie tylko pedagodzy, ale też i psychologowie, socjolodzy, antropolodzy, filozofowie, a także reprezentanci nauk o zdrowiu. Konferencja od początku organizowana była jako dwudniowe wydarzenie.

Poniżej przedstawiono wykaz doczasowych zrealizowanych spotkań:

- 2014 - I Konferencja Gerontologiczna z cyklu: Refleksje nad Starością „Obiektywny i subiektywny wymiar starości”.

- 2016 - II Konferencja Gerontologiczna z cyklu: Refleksje nad Starością „Starość w nurcie życia".

- 2018 - III Konferencja Gerontologiczna z cyklu: Refleksje nad Starością „Być i stawać się w starości".

Oprócz konferencji gerontologicznych Katedra Andragogiki i Gerontologii Społecznej powołała do życia serię wydawniczą „Refleksje nad starością”. Do tej pory ukazały się dwa tomy nakładem Wydawnictwa Uniwersytetu Łódzkiego. Oba pod redakcją Elżbiety Dubas i Marcina Muszyńskiego. Pierwszy tom pod tytułem Obiektywny i subiektywny wymiar starości ukazał się w 2016 r. Monografia stanowi zbiór multidyscyplinarnych tekstów, dotyczących różnych aspektów starości, jej postrzegania i interpretowania. Zasadnicza refleksja podjęta w publikacji odnosi się do pytania o możliwość zobiektywizowania starości, zamknięcia tej tematyki w liczbach i statystycznych ujęciach bądź też w uproszczonym zbiorowym portrecie, z którego wynikałoby, że większość osób w zaawansowanym wieku ma takie same problemy i potrzeby. Autorzy zastanawiają się, co kształtuje społeczny i indywidualny obraz starości, jak powstają stereotypy jej dotyczące, a następnie zadają pytanie, jaka jest prawdziwa starość. Istotnym wątkiem badawczym w prezentowanym tomie jest subiektywny wymiar starości ukazywany w różnorakich aspektach, także w odniesieniu do odbicia w owym lustrze społecznym. 
Drugi tom ukazał się w 2019 r. pod tytułem Starość w nurcie życia. Tym razem podjęta problematyka mieściła się pomiędzy dwoma biegunami nurtu życiowego - społeczno-kulturowym i jednostkowym przeżywaniem starości. Publikacja dotyczy procesów migracyjnych, które coraz częściej wpływają na ludzi starszych i lokują starość w kontekście interakcji globalnych; działań lokalnych, środowiskowych i instytucjonalnych podejmowanych na rzecz seniorów; zagadnień związanych z postawami wobec osób starszych, dyskryminacją ze względu na wiek, zdrowiem, jakością życia i ekoterapią; zindywidualizowanego doświadczania starości w kontekście uczenia się oraz w trudnych sytuacjach życiowych, takich jak choroba czy przemoc domowa.

Obie opisane pozycje serii wydawniczej „Refleksje nad starością” znalazły zainteresowanie wśród badaczy, studentów i doktorantów zajmujących się problematyką gerontologiczną (pedagogów, socjologów, psychologów) oraz instytucji wspierających osoby starsze (domy pomocy społecznej, uniwersytety trzeciego wieku).

\section{Bibliografia}

Dubas E., Muszyński M. (red.) (2016) Obiektywny i subiektywny wymiar starości, Łódź, Wydawnictwo Uniwersytetu Łódzkiego.

Dubas E., Muszyński M. (red.) (2019) Starość w nurcie życia, Łódź, Wydawnictwo Uniwersytetu Łódzkiego. 